University of Nebraska - Lincoln

DigitalCommons@University of Nebraska - Lincoln

Publications, Agencies and Staff of the U.S.

Department of Commerce

U.S. Department of Commerce

$10-2002$

\title{
Diets of Baird's Beaked Whales, Berardius bairdii, in the Southern Sea Of Okhotsk and Off the Pacific Coast Of Honshu, Japan
}

\author{
William A. Walker \\ NOAA \\ James G. Mead \\ National Museum of Natural History, Washington, DC \\ Robert L. Brownell Jr. \\ National Marine Fisheries Service, NOAA, rlbcetacea@aol.com
}

National Marine Mammal Laboratory, Alaska Fisheries Science Center, National Marine Fisheries Service,

Follow this and additional works at: https://digitalcommons.unl.edu/usdeptcommercepub

Part of the Environmental Sciences Commons

Walker, William A.; Mead, James G.; and Brownell, Robert L. Jr., "Diets of Baird's Beaked Whales, Berardius bairdii, in the Southern Sea Of Okhotsk and Off the Pacific Coast Of Honshu, Japan" (2002). Publications, Agencies and Staff of the U.S. Department of Commerce. 107.

https://digitalcommons.unl.edu/usdeptcommercepub/107

This Article is brought to you for free and open access by the U.S. Department of Commerce at DigitalCommons@University of Nebraska - Lincoln. It has been accepted for inclusion in Publications, Agencies and Staff of the U.S. Department of Commerce by an authorized administrator of DigitalCommons@University of Nebraska - Lincoln. 


\title{
DIETS OF BAIRD'S BEAKED WHALES, BERARDIUS BAIRDII, IN THE SOUTHERN SEA OF OKHO'TSK AND OFF THE PACIFIC COAST OF HONSHU, JAPAN
}

\author{
William A. WALKer \\ National Marine Mammal Laboratory, \\ Alaska Fisheries Science Center, \\ National Marine Fisheries Service, NOAA, \\ 7600 Sand Point Way, N.E., \\ Seattle, Washington 98115 , U.S.A. \\ E-mail: mindwalk@msn.com \\ JAMES G. MeAD \\ Division of Mammals, \\ National Museum of Natural History, \\ Washington, DC 20560, U.S.A. \\ ROBERT L. BROWNELL JR. \\ Southwest Fisheries Science Center, \\ National Marine Fisheries Service, NOAA, \\ P. O. Box 271, \\ La Jolla, California 92038, U.S.A.
}

\begin{abstract}
Stomach contents were analyzed from 127 Baird's beaked whales, Berardius bairdii, taken in coastal waters of Japan. During late July-August of 19851987, 1989, and 1991, 107 samples were collected from off the Pacific coast of Honshu. An additional 20 samples were collected from whales taken in the southern Sea of Okhotsk during late August-September of 1988 and 1989. Prey identification using fish otoliths and cephalopod beaks revealed the whales fed primarily on deep-water gadiform fishes and cephalopods in both regions. Prey species diversity and the percentage of cephalopods and fish differed between the two regions. Off the Pacific coast of Honshu the whales fed primarily on benthopelagic fishes (81.8\%) and only $18.0 \%$ on cephalopods. Eight species of fish representing two families, the codlings (Moridae) and the grenadiers (Macrouridae), collectively made up $81.3 \%$ of the total. Thirty species of cephalopods representing 14 families made up $12.7 \%$. In the southern Sea of Okhotsk, cephalopods accounted for $87.1 \%$ of stomach contents. The families Gonatidae and Cranchiidae were the predominant cephalopod prey, accounting for $86.7 \%$ of the diet. Gadiform fish accounted for only $12.9 \%$ of the diet. Longfin codling, Laemonema longipes, was the dominant fish prey in both regions. Depth distribution of the two commonly consumed fish off the Pacific coast of
\end{abstract}


Honshu indicate the whales in this region fed primarily at depths ranging from 800 to $1,200 \mathrm{~m}$.

Key words: Baird's beaked whale, Berardius bairdii, Ziphiidae, diet, cephalopods, Moridae, Macrouridae, Laemonema longipes, Coryphaenoides cinereus, Coryphaenoides longifilis.

The deep-diving behavior of Baird's beaked whale, Berardius bairdii, is well known (Balcomb 1989). Prolonged dives for periods of up to $67 \mathrm{~min}$ have been reported for this species (Kasuya 1986). Despite historically large numbers of $B$. bairdii taken in whaling operations throughout its range in the northern North Pacific, little is known about their foraging behavior and role in the marine ecosystem.

The diet of $B$. bairdii is poorly known and most of the literature accounts rely on small sample sizes. Pike (1953) and Rice (1963) reported on eight whales taken in the eastern North Pacific. Betesheva (1961) reported on the stomach contents of 12 whales taken off the Kurile Islands, whereas Tomilin (1957) did so for five whales presumably taken off the Kamchatka Peninsula (precise localities were not given). Nishiwaki and Oguro (1971) summarized findings based on a cursory examination of stomach contents of 383 whales taken along the Pacific coast of Honshu, Japan, to the northern coast of Hokkaido in the southern Sea of Okhotsk. Though they had access to a large sample of whales, they limited their findings almost exclusively to regional accounts on general qualitative observations of the numbers of stomachs predominantly containing remains of "deep sea fish" or "squid."

This study is based on a detailed examination of stomach contents collected from 127 Baird's beaked whales taken off the Pacific coast of Honshu, Japan, and in the southern Sea of Okhotsk off the northern coast of Hokkaido. It not only represents the first detailed quantitative prey species description for this species of whale, but also constitutes the most comprehensive diet study conducted on any member of the family Ziphiidae.

\section{METHODS}

\section{Field Collection}

Stomach samples collected in this study were from whales taken in the coastal, shore-based small whaling fisheries currently operating under permit by the Japanese Ministry of Agriculture and Forestry. These operations employ the use of high-speed catcher vessels of approximately 40 tons with a deck-mounted 50-mm bore harpoon gun (Ohsumi 1975). The whale fisheries take of B. bairdii off the coast of Japan is seasonal and corresponds to the whales' natural migratory movements. It first appears off the continental slope of the Pacific coast of Honshu at approximately $34^{\circ} \mathrm{N}$ in early summer and moves northward as the season progresses through late fall (Kasuya et al. 1997).

Due to time constraints, logistics, and stomach condition, all whales processed at any given whaling station were not necessarily sampled. With the exception of the work at Abashiri in 1988 that was performed by a Japanese Fisheries 


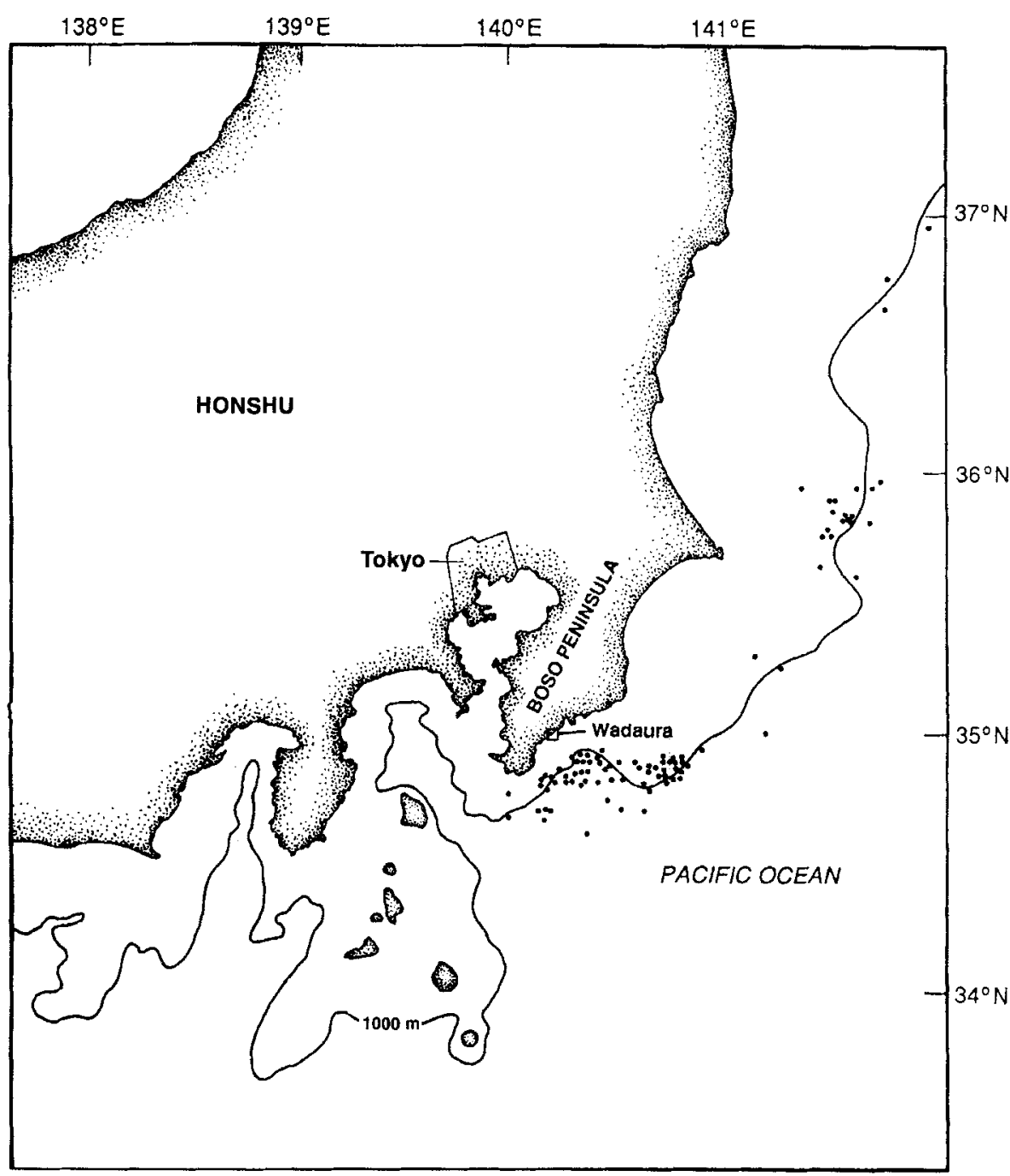

Figure 1. Approximate capture locations for Berardius bairdii stomach samples collected off Pacific coast of Honshu, Japan 1985-1987, 1989, and 1991.

Agency biologist, all other fieldwork was conducted by one or more of the authors.

The sample collected off the Pacific coast of Honshu, Japan, was taken off the Boso Peninsula and Sanriku coast in an area extending from approximately $34^{\circ} 30^{\prime}$ to $36^{\circ} 50^{\prime} \mathrm{N}$ (Fig. 1). Stomach contents from a total of 107 whales were collected during the 1985-1987, 1989, and 1991 seasons in late July through August of each year. Of these, 104 were processed at the Gaibo whaling station at Wadaura, Chiba Prefecture, whereas, three were sampled from the northern part of this region in 1991 at Ayukawa, Miyagi Prefecture. 


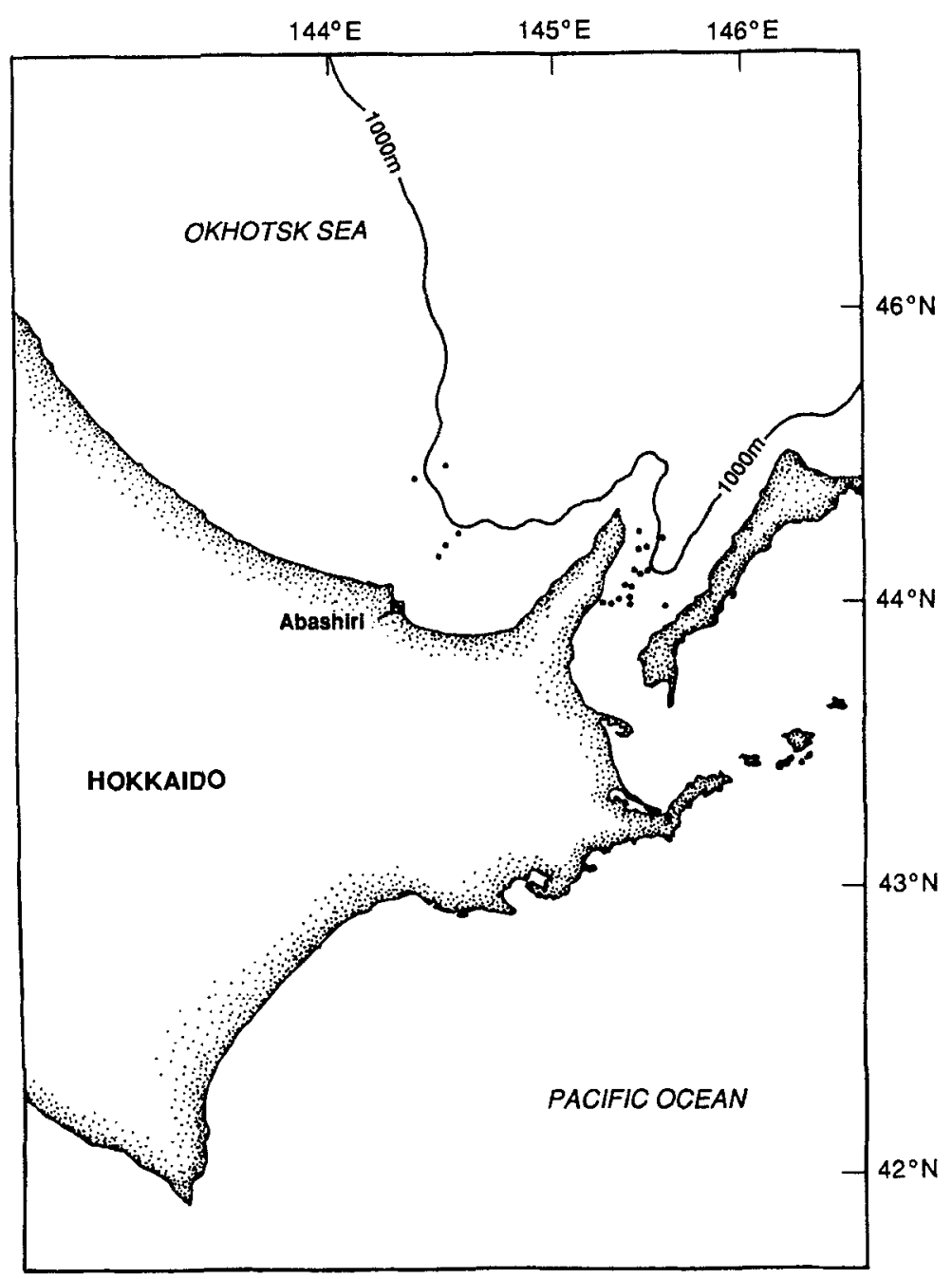

Figure 2. Approximate capture locations for Berardius bairdii stomach samples collected in southern Sea of Okhotsk 1988-1989.

The Sea of Okhotsk sample was collected during late August through September off Abashiri, Hokkaido, and in the Nemaro Strait between the eastern side of the Shirotoko Peninsula and Kunashir Island (Fig. 2). A total of 20 whales were sampled during the 1988 and 1989 seasons.

Once the viscera had been removed from the carcass, the esophagus and small intestine (just posterior to the duodenum) were tied off with twine. The entire stomach was then cut free from the surrounding organs and removed to a work area clear of the flensing operation. The stomach was opened in a systematic manner beginning at the esophageal junction and terminating with examination of the duodenum. All stomach contents were removed and placed in large 
containers. The final procedure in the removal of food remains was to gently rinse the entire mucosal surface with fresh water. All isolated otoliths and cephalopod beaks adhering to the mucosal folds were then collected. Stomach contents were weighed if estimated to exceed $5 \mathrm{~kg}$. Contents were placed in trays and rinsed with water to remove excess prey tissue. All identifiable remains such as cephalopod beaks, otoliths, representative fish crania, and other diagnostic bones were preserved in $70 \%$ ethanol. Due to the practice of opening the body cavity at sea to cool the carcass and the effect of exploding harpoon heads, some stomachs were inadvertently damaged and the contents lost or partially lost while the animals were towed to the port facility. This study reports only on undamaged stomachs containing food remains. Due to the difficulty in interpreting the significance of empty stomachs, they were also excluded from the sample.

\section{Laboratory Analyses}

Prey species were identified from fish saggital otoliths and cephalopod beaks. Confirmation of beak and otolith identifications were aided through identification of fish cranial bones and intact, or partially intact, fish and cephalopod remains whenever possible.

The minimum number of individual prey ingested was determined by the greater number of left or right otoliths and upper or lower cephalopod beaks. In instances where badly eroded, but specifically identifiable, otoliths could not be determined to be left or right, the total number was divided by two to estimate the number of fish represented. Otolith length (OL), otolith width (OW), lower rostral length (LRL) of squid beaks and lower hood length (LHL) of vampyromorph and octopod beaks were measured to the nearest $0.1 \mathrm{~mm}$ with either vernier calipers or an optical micrometer. All otoliths and beaks were measured if they were judged to be in good condition. Damaged or eroded otoliths and beaks were not measured. Prey species taxonomy and nomenclature follow Nelson (1994) and Masuda et al. (1984) for fishes and Nesis (1987) for cephalopods.

Deep-water lanternfishes, juvenile squid, and a wide range of benthic invertebrates are reported as prey of macrourid fishes in the coastal waters of Japan (Okamura 1970a). Myctophid fishes and juvenile squid are also well-known diet components of numerous species of cephalopods. Beaked whales capture their prey primarily by means of suction (Heyning and Mead 1996), a feeding strategy conducive to incidental ingestion. Otoliths from small fishes, which were probably incidentally ingested in pursuit of larger prey or secondarily introduced as prey of larger prey consumed by the whales were evident in the stomach samples from both regions. These specimens are not listed in the prey species tables. These otoliths occurred infrequently and were from small fish estimated to be no more than $100 \mathrm{~mm}$ in length. Many of these otoliths were severely eroded and some exhibited sharp angular chips and breakage suggesting secondary introduction as prey of cephalopods. In the Pacific coast of Honshu sample, a total of 32 otoliths representing two families, Myctophidae (five genera; Diaphus, Electrona, Stenobracbius, Myctophum, and Lampanyctus) and Bathylagidae (Batbylagus sp.) were considered to be incidentally or secondarily introduced. In the southern Sea of Okhotsk sample, otoliths suspected to be of incidental or secondary origin were from small walleye pollock, Theragra chalcogramma (nine otoliths, $2-4 \mathrm{~mm}$ in length) and an unidentified species of small juvenile, zoarcid (seven otoliths). Similarly, beaks from infrequently occurring, small cephalopods were also considered 
to be incidentally ingested or introduced secondarily and excluded from the prey species lists. In the Pacific coast sample these were six beaks from Abraliopsis felis (0.5-1.0 mm LRL) and four Helicocranchia sp. beaks $(0.5-0.9 \mathrm{~mm} \mathrm{LRL})$. In the Sea of Okhotsk sample, 11 beaks from small juvenile Gonatus spp. (0.5-1.0 mm LRL) were not included as prey.

Little is known about the life history of most of the prey species consumed by the whales. This is particularly true for many of the species of grenadiers. Literature reports on growth rates and length/weight relationships are almost non-existent for many of the common prey. This lack of information prevents estimation of prey size, weight, and contribution by mass for a large percentage of the sample. However, we recently developed otolith length/body length (fishes), lower beak rostral length/dorsal mantle length (cephalopods), and length/weight regressions for eight of the commonly ingested prey (Table 1). Otolith and cephalopod beak samples from specimens of known length and weight were obtained from specimens retained at the Northwest and Alaska Fisheries Science Center Seattle, Washington, and Scripps Institute of Oceanography, La Jolla, California.

\section{RESULTS}

\section{Pacific Coast of Honshu, Japan}

Stomach content analysis of the 107 whales sampled from this region revealed the whales fed primarily on fish (81.8\%) and to a lesser degree on cephalopods $(18.0 \%)$. Two families of benthopelagic gadiform fishes made up $81.3 \%$ of the prey (Table 2). The codlings (Moridae) were represented by two species: the longfin codling, Laemonema longipes (43.5\%), and the finescale mora, Antimora microlepis $(0.5 \%)$ with a combined frequency of occurrence of $85.6 \%$. Six species of grenadiers (Macrouridae) made up $37.3 \%$ of the prey by number, with a frequency of occurrence of $93.5 \%$. Of these, three species of Coryphaenoides $(C$. longifilis, $C$. cinereus, and $C$. acrolepis) were predominant and collectively accounted for $33.2 \%$ of the prey consumed.

Despite the low numbers of cephalopod prey, the frequency of occurrence in the sample was high $(92.5 \%)$. The species composition of cephalopods eaten by $B$. bairdii in this region was diverse. Thirty species encompassing 14 families of cephalopods were represented. Two families were dominant; eight species of the family Gonatidae accounted for $7.8 \%$ of the total prey with a frequency of $83.2 \%$. The family Cranchiidae, represented by six species, accounted for $4.9 \%$ of the total prey in $98.1 \%$ of the stomachs.

The two dominant fish prey, $L$. longipes and $C$. cinereus, collectively made up $58.4 \%$ of the total prey in this region. The estimated mean standard length of $L$. longipes in the sample was $510.1 \mathrm{~mm}$. The estimated mean pre-anal fin length and weight for $C$. cinereus were $119.2 \mathrm{~mm}$ and $199.6 \mathrm{~g}$, respectively (Table 3).

The presence of gravel and stones up to $9 \mathrm{~cm}$ in diameter in the stomachs of the Pacific coast of Honshu sample was high. They were present in all of 98 stomachs surveyed for these non-food items.

\section{Soutbern Sea of Okbotsk}

In the southern Sea of Okhotsk the dominant prey of $B$. bairdii shifted considerably. Cephalopods dominated the diet, collectively accounting for $87.1 \%$ of the 


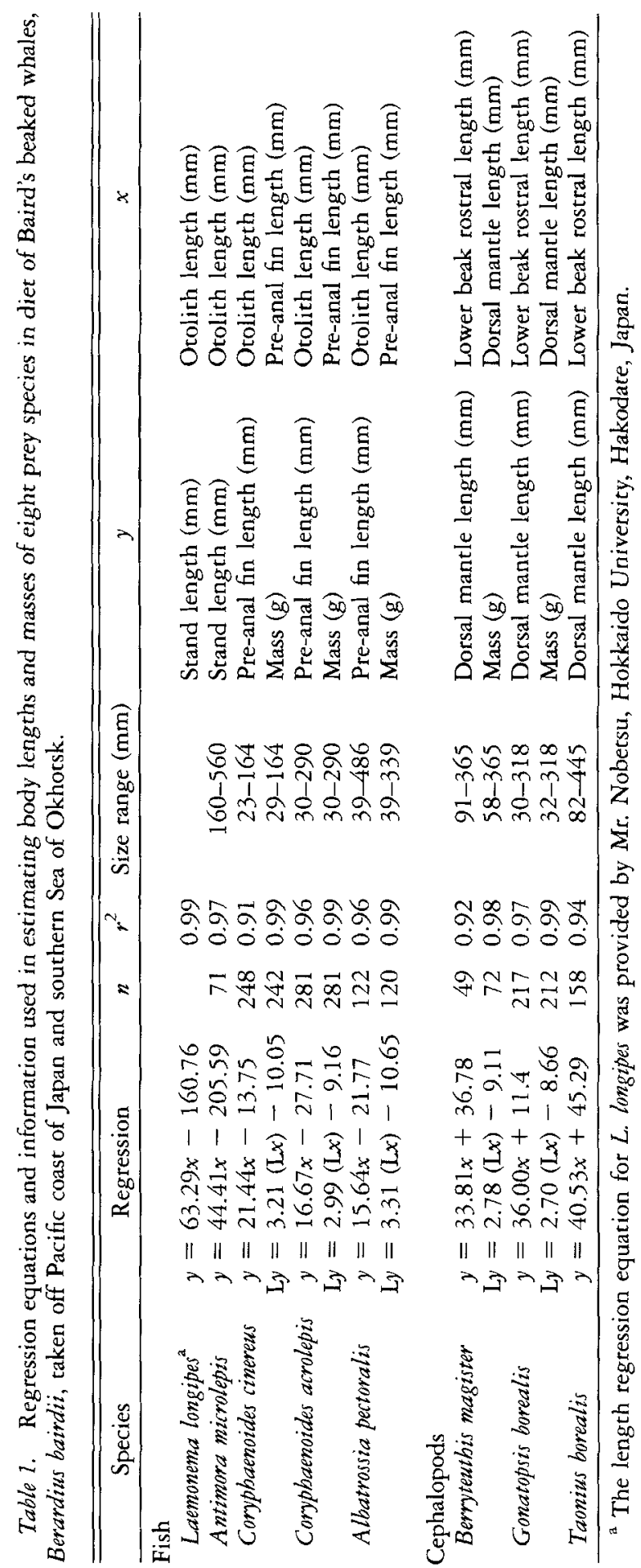


prey consumed with a frequency of occurrence of $100 \%$ (Table 4). The number of cephalopod species represented was less diverse than that of the Pacific coast of Honshu sample. Only four families of cephalopods were represented. However, the two families Gonatidae and Cranchiidae remained the dominant cephalopod prey and collectively represented $86.7 \%$ of the total prey consumed. Six species of gonatid squid were represented and accounted for $75.8 \%$ of the total. Of the gonatids, the schoolmaster gonate squid, Berryteutbis magister, was dominant species and accounted for a total of $31.7 \%$ of the prey and occurred in all the stomachs. The family Cranchiidae was represented by three species, accounting for $10.9 \%$ of the prey with a frequency of occurrence of $95 \%$.

Fish were less important in this region representing only $12.9 \%$ by number with an occurrence of $90 \%$. Four families of fishes were represented. Moridae and Macrouridae remained the dominant fish prey and collectively made up 9.2\% of the total. Morids were represented by a single species, L. longipes, which accounted for $3.4 \%$ of the total with an occurrence of $45.0 \%$. Three species of Macrouridae ( $C$. cinereus, $C$. acrolepis, and Albatrossia pectoralis) made up $5.8 \%$ of the total prey in $50.0 \%$ of the stomachs examined. The walleye pollock, Theragra chalcogramma (Gadidae) and two species of eelpout (Zoarcidae) collectively made up the remaining $3.7 \%$ of the total prey.

Though the longfin codling, $L$. longipes, remained the dominant fish species in the sample, the estimated mean length of $358.2 \mathrm{~mm}$ was smaller than those consumed by the whales off the Pacific coast of Honshu (Table 5). The estimated mean length and weight of the dominant cephalopod in the sample, B. magister, was $213.7 \mathrm{~mm}$ and $331.2 \mathrm{~g}$, respectively.

The presence of non-food items in the stomachs of the southern Sea of Okhotsk whales was comparatively low. Gravel and stones were found in only two $(10.0 \%)$ of the 20 stomachs examined.

\section{DisCUSSION}

The results of this study are generally similar to the qualitative findings of Nishiwaki and Oguro (1971). Their observation that Baird's beaked whales feed primarily on squid off the northern coast of Hokkaido and on "deep sea fish" off the Pacific coast of Japan is supported by our findings. They also reported "sardine" (presumably Sardinops melanosticta) and "mackerel" (presumably Scomber sp.) as prey of whales taken off the Pacific coast of Honshu north of $37^{\circ} \mathrm{N}$. Sardine and mackerel are primarily inhabitants of the epipelagic zone. If their observations are correct this would indicate a shift in Baird's beaked whale feeding behavior in this region. We are unable to confirm this observation since all our stomach samples off the Pacific coast of Japan were collected from south of that latitude.

The two major gadiform fish families represented in our study (Moridae and Macrouridae) are of confirmed deep-water, benthic habit and many are known to occur at depths in excess of $1,000 \mathrm{~m}$ (Okamura 1970a, b). The morid, Laemonema longipes, and the macrourids, Coryphaenoides acrolepis and Albatrossia pectoralis, are reported as prey of Baird's beaked whales taken off the Kurile Islands (Betesheva (1961). Rice (1963) reported the macrourid species, C. acrolepis, from B. bairdii taken off central California.

The longfin codling, L. longipes, was the dominant fish prey in both the southern Sea of Okhotsk and Pacific coast of Honshu samples. Yokota and Kawasaki 
Table 2. Number and frequency of occurrence of prey recovered from 107 stomachs from Baird's beaked whales, Berardius bairdii, taken off Pacific coast of Honshu, Japan.

\begin{tabular}{|c|c|c|c|c|}
\hline & \multicolumn{2}{|c|}{ Number } & \multicolumn{2}{|c|}{ Occurrence } \\
\hline & No. & $\%$ of Total & No. & $\%$ Frequency \\
\hline Total prey & 9,880 & 100 & 107 & 100 \\
\hline Fish & 8,078 & 81.8 & 104 & 97.2 \\
\hline \multicolumn{5}{|l|}{ Synaphobranchidae } \\
\hline Synapbobrancbus affinis & 1 & $<0.1$ & 1 & 0.9 \\
\hline \multicolumn{5}{|l|}{ Alepocephalidae } \\
\hline Alepocephalus sp. & 2 & $<0.1$ & 2 & 1.9 \\
\hline \multicolumn{5}{|l|}{ Alepisauridae } \\
\hline Alepisaurus ferox & 2 & $<0.1$ & 2 & 1.9 \\
\hline Moridae & 4,343 & 44.0 & 89 & 85.6 \\
\hline Antimora microlepis & 46 & 0.5 & 18 & 16.8 \\
\hline Laemonema longipes & 4,297 & 43.5 & 86 & 80.4 \\
\hline \multicolumn{5}{|l|}{ Macrouroididae } \\
\hline Squalogadus modificatus & 43 & 0.4 & 5 & 4.7 \\
\hline Macrouridae & 3,683 & 37.3 & 100 & 93.5 \\
\hline Batbygadus antrodes & 21 & 0.2 & 6 & 5.6 \\
\hline Albatrossia pectoralis & 7 & 0.1 & 5 & 4.7 \\
\hline Coryphaenoides longifli is & 1,347 & 13.6 & 76 & 71.0 \\
\hline Coryphaenoides acrolepis & 467 & 4.7 & 63 & 58.9 \\
\hline Coryphaenoides cinereus & 1,469 & 14.9 & 83 & 77.6 \\
\hline Coelorinchus japonicus & 304 & 3.1 & 18 & 16.8 \\
\hline Unidentifiable macourid otoliths (worn) & 68 & 0.7 & 13 & 12.1 \\
\hline \multicolumn{5}{|l|}{ Gempylidae } \\
\hline Rexea solandri & 4 & $<0.1$ & 4 & 3.7 \\
\hline Cephalopoda & 1,782 & 18.0 & 99 & 92.5 \\
\hline Enoploteuthidae & 136 & 1.4 & 35 & 32.7 \\
\hline Enoploteutbis chuni & 131 & 1.3 & 34 & 31.8 \\
\hline Ancistrocheirus lesueuri & 5 & 0.1 & 4 & 3.7 \\
\hline \multicolumn{5}{|l|}{ Octopoteuthidae } \\
\hline Octopoteutbis deletron & 17 & 0.2 & 9 & 8.4 \\
\hline Onychoteuthidae & 32 & 0.3 & 18 & 16.8 \\
\hline Onychoteutbis borealijaponica & 13 & 0.1 & 8 & 7.5 \\
\hline Moroteutbis lonnbergi & 19 & 0.2 & 14 & 13.1 \\
\hline Gonatidae & 769 & 7.8 & 89 & 83.2 \\
\hline Gonatus onyx & 28 & 0.3 & 11 & 10.3 \\
\hline Gonatus pyros & 61 & 0.6 & 31 & 29.0 \\
\hline Gonatus berryi & 103 & 1.0 & 39 & 36.5 \\
\hline Gonatus madokai & 24 & 0.2 & 11 & 10.3 \\
\hline Gonatus sp. A & 63 & 0.6 & 33 & 30.8 \\
\hline Gonatus spp.(damaged) & 5 & 0.1 & 3 & 2.8 \\
\hline Gonatopsis sp. A. & 68 & 0.7 & 26 & 24.3 \\
\hline Gonatopsis borealis & 75 & 0.8 & 40 & 37.4 \\
\hline Eogonatus tinro & 344 & 3.5 & 65 & 62.5 \\
\hline Histioteuthidae & 29 & 0.3 & 15 & 14.0 \\
\hline Histioteuthis boylei & 27 & 0.3 & 15 & 14.0 \\
\hline Histioteuthis corona & 2 & $<0.1$ & 1 & 0.9 \\
\hline \multicolumn{5}{|l|}{ Architeuthidae } \\
\hline Arcbiteutbis sp. & 1 & $<0.1$ & 1 & 0.9 \\
\hline Ommastrephidae & 61 & 0.6 & 21 & 19.6 \\
\hline
\end{tabular}


Table 2. Continued.

\begin{tabular}{|c|c|c|c|c|}
\hline & \multicolumn{2}{|c|}{ Number } & \multicolumn{2}{|c|}{ Occurrence } \\
\hline & No. & $\%$ of Total & No. & $\%$ Frequency \\
\hline Todarodes pacificus & 58 & 0.6 & 22 & 20.6 \\
\hline Unidentif. Ommastrephidae & 3 & 0.1 & 3 & 2.8 \\
\hline Chiroteuthidae & 12 & 0.1 & 3 & 2.8 \\
\hline Chiroteutbis calyx & 4 & $<0.1$ & 3 & 2.8 \\
\hline Chiroteutbis sp. A & 8 & 0.1 & 3 & 2.8 \\
\hline \multicolumn{5}{|l|}{ Mastigoteuthidae } \\
\hline Mastigoteuthis sp. cf. $M$. dentata & 218 & 2.2 & 53 & 49.5 \\
\hline Cranchiidae & 487 & 4.9 & 105 & 98.1 \\
\hline Leacbia sp. & 5 & 0.1 & 4 & 3.7 \\
\hline Megalocranchia sp. & 5 & 0.1 & 4 & 3.7 \\
\hline Taonius borealis & 388 & 3.9 & 81 & 75.7 \\
\hline Galiteutbis sp. A & 5 & 0.1 & 5 & 4.7 \\
\hline Galiteutbis sp. B & 14 & 0.1 & 7 & 6.5 \\
\hline Galiteutbis phyllura & 69 & 0.7 & 34 & 31.8 \\
\hline \multicolumn{5}{|l|}{ Vampyroteuthidae } \\
\hline Vampyroteutbis infernalis & 8 & 0.1 & 8 & 7.5 \\
\hline \multicolumn{5}{|l|}{ Octopodidae } \\
\hline Octopus dofleini & 5 & 0.1 & 4 & 3.7 \\
\hline \multicolumn{5}{|l|}{ Alloposidae } \\
\hline Alloposus mollis & 5 & 0.1 & 5 & 4.7 \\
\hline \multicolumn{5}{|l|}{ Ocythoidae } \\
\hline Ocythoe tuberculata & 2 & $<0.1$ & 2 & 1.9 \\
\hline \multicolumn{5}{|l|}{ Pyrosomata } \\
\hline Pyrosoma allanticum & 20 & 0.2 & 11 & 10.3 \\
\hline
\end{tabular}

(1990) report that mature individuals migrate south along the Pacific coast of Honshu in winter to spawn in an area just south of the tip of the Boso peninsula $\left(\sim 34^{\circ} \mathrm{N}\right)$ in late winter to spring. Subsequent to spawning, they then migrate northward back up the coast of Honshu. It is interesting to note that in this region the seasonal movements of $B$. bairdii and seasonal spawning and northward migration of its primary prey, $L$. longipes, coincide. The occurrence of $B$. bairdii in the coastal waters of Japan is also seasonal (early summer to late autumn). The whales first appear off the Pacific coast of Japan at approximately $34^{\circ} \mathrm{N}$ latitude in early summer and spread northward as the season progresses (Kasuya 1986, Kasuya et al. 1997). It may be that the movements of Baird's beaked whales off the Pacific coast of Japan are related to the seasonal spawning migration of longfin codling. The minimum lengths of $L$. longipes at maturity for males and females are $358 \mathrm{~mm}$ and $410 \mathrm{~mm}$, respectively (Hamatsu and Yabuki 1997). The estimated mean length of $510.1 \mathrm{~mm}$ for $L$. longipes consumed by $B$. bairdii off the Pacific coast of Honshu in July and August reveals most of these fish were mature and were probably eaten subsequent to spawning or in the early stages of their northward migration. The estimated mean length of $L$. longipes consumed by the whales in the southern Sea of Okhotsk during late August through September was much smaller $(358.2 \mathrm{~mm})$, indicating that the whales were feeding on a large percentage of immature fish. 


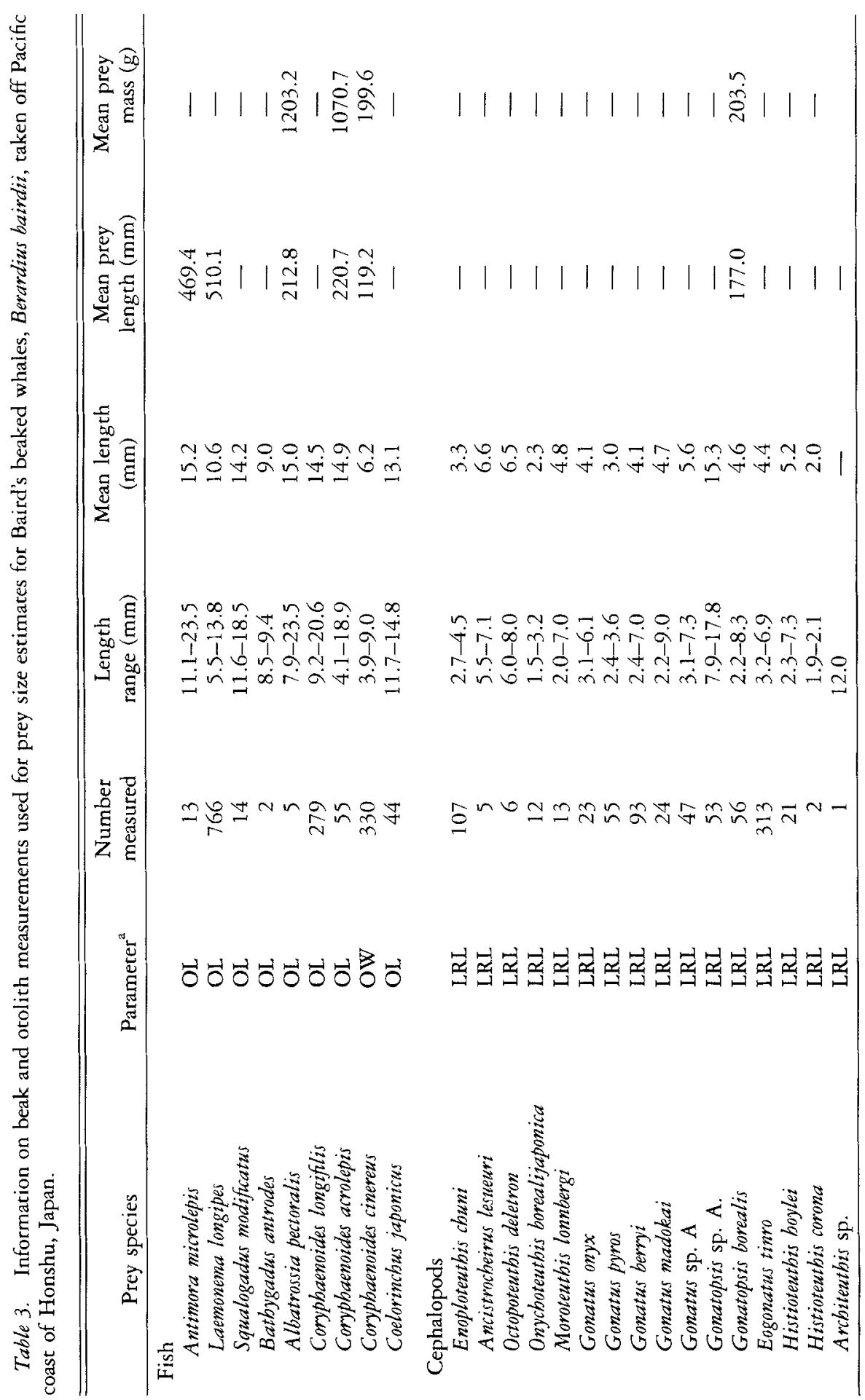




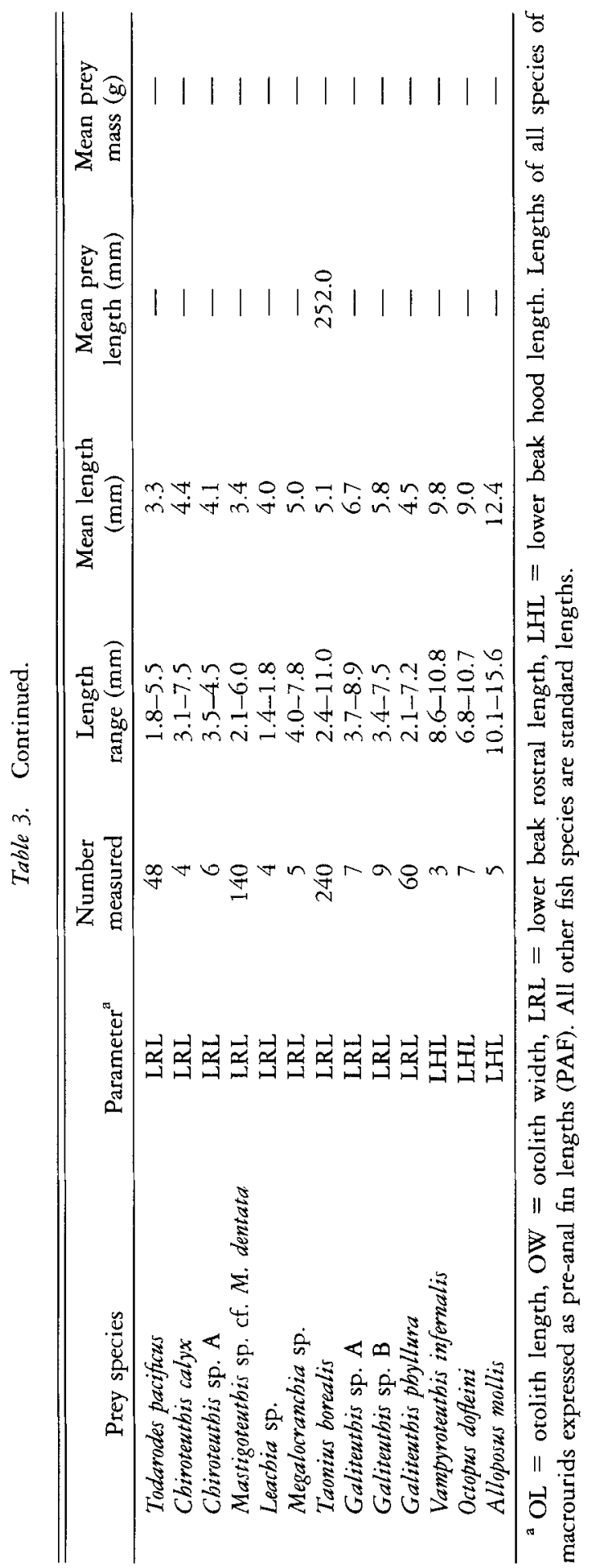


Table 4. Number and frequency of occurrence of prey recovered from 20 stomachs from Baird's beaked whales, Berardius bairdii, taken in southern Sea of Okhorsk.

\begin{tabular}{|c|c|c|c|c|}
\hline & \multicolumn{2}{|c|}{ Number } & \multicolumn{2}{|c|}{ Occurrence } \\
\hline & No. & $\%$ of Total & No. & $\%$ Frequency \\
\hline Total prey & 2,432 & 100 & 20 & 100 \\
\hline Fish & 315 & 12.9 & 18 & 90.0 \\
\hline \multicolumn{5}{|l|}{ Moridae } \\
\hline Laemonema longipes & 83 & 3.4 & 9 & 45.0 \\
\hline \multicolumn{5}{|l|}{ Gadidae } \\
\hline Theragra chalcogramma & 44 & 1.8 & 9 & 45.0 \\
\hline Macrouridae & 140 & 5.8 & 10 & 50.0 \\
\hline Albatrossia pectoralis & 62 & 2.6 & 5 & 25.0 \\
\hline Coryphaenoides acrolepis & 4 & 0.2 & 3 & 15.0 \\
\hline Coryphaenoides cinereus & 74 & 3.0 & 7 & 35.0 \\
\hline Zoarcidae & 48 & 2.0 & 11 & 55.0 \\
\hline Botbrocarina microcepbala & 46 & 1.9 & 11 & 55.0 \\
\hline Botbrocara molle & 2 & 0.1 & 1 & 5.0 \\
\hline Cephalopods & 2,117 & 87.1 & 20 & 100.0 \\
\hline Gonatidae & 1,843 & 75.8 & 20 & 100.0 \\
\hline Gonatus onyx & 1 & $<0.1$ & 1 & 5.0 \\
\hline Gonatus berryi & 244 & 10.0 & 17 & 85.0 \\
\hline Gonatus madokai & 355 & 14.6 & 19 & 95.0 \\
\hline Gonatopsis sp. A. & 132 & 5.4 & 13 & 65.0 \\
\hline Berryteutbis magister & 771 & 31.7 & 20 & 100.0 \\
\hline Eogonatus tinro & 340 & 14.0 & 18 & 90.0 \\
\hline \multicolumn{5}{|l|}{ Histioteuthidae } \\
\hline Histioteutbis boylei & 1 & $<0.1$ & 1 & 5.0 \\
\hline Cranchiidae & 265 & 10.9 & 19 & 95.0 \\
\hline Taonius borealis & 64 & 2.6 & 16 & 80.0 \\
\hline Galiteutbis sp.A & 83 & 3.4 & 12 & 60.0 \\
\hline Galiteutbis pbyllura & 118 & 4.8 & 16 & 80.0 \\
\hline \multicolumn{5}{|l|}{ Octopoda } \\
\hline Octopus dofleini & 8 & 0.3 & 1 & 5.0 \\
\hline
\end{tabular}

Detailed experimental fishery information on the depth distribution and relative abundance of two of the most common fish prey off the Honshu coast shed some light on the foraging behavior of $B$. bairdii. In the stomach samples collected from whales taken off the Pacific coast of Honshu, the longfin codling, $L$. longipes, and the longfin grenadier, $C$. longiflis, collectively made up $57.1 \%$ of the total number of prey. Shiratori and Kawasaki (1989) reported on a series of deep-water bottom trawls conducted at various depths on the continental slope at approximately $38^{\circ} \mathrm{N}$ off the Honshu coast (Fig. 3). In this region the bottom depth distribution of $L$. longipes ranged from 600 to $1,000 \mathrm{~m}$, reaching their greatest abundance at $800-900 \mathrm{~m}$. The bottom depth distribution of $C$. longifilis ranged from 1,000 to $1,500 \mathrm{~m}$, with the greatest concentration of this species at $1,200 \mathrm{~m}$. They also reported two species of gadids, walleye pollock, Theragra chalcogramma, and Pacific cod, Gadus macrocephalus, to be the most abundant fishes in trawl samples at bottom depths ranging from 100 to $400 \mathrm{~m}$. The latter 


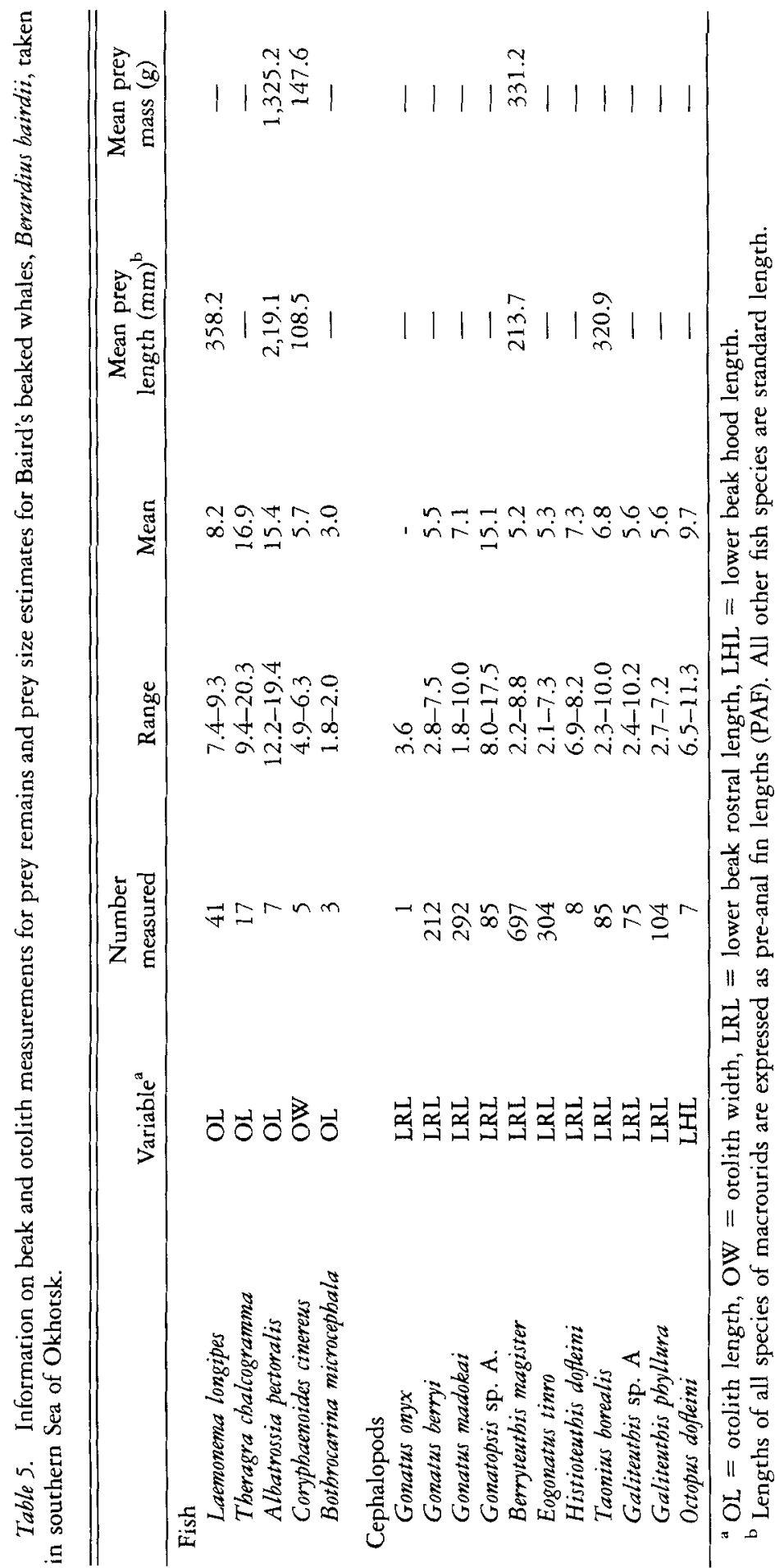




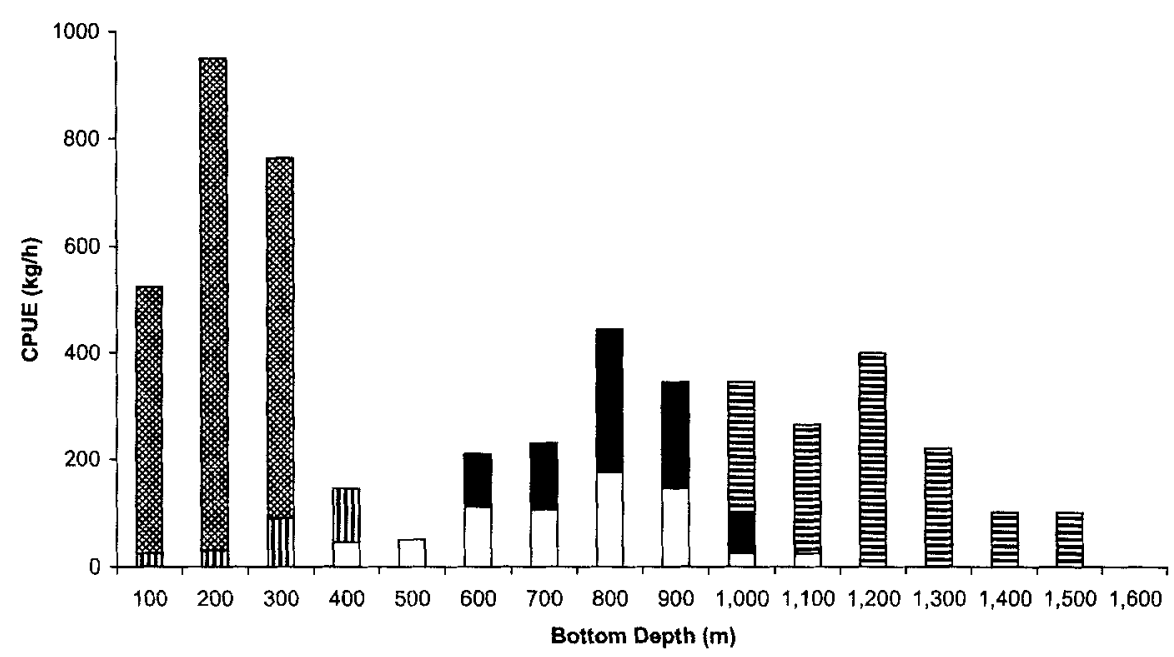

DOther species* ${ }^{*}$ Laemonema longipes $\mathbf{m}$ Gadus macrocephalus Theragra chalcogramma ECoryphaenoides longintis

Figure 3. Bottom depth distribution and relative abundance of fishes taken by bottom trawl at approximately $38^{\circ} \mathrm{N}$ on continental slope of Pacific coast of Honshu (figure modified from Shiratori and Kawasaki 1989). * Other species taken from below $800 \mathrm{~m}$ were primarily roughscale sole, Clidoderma asperrimum, popeye grenadier, Coryphaenoides cinereus, Pacific grenadier, C. acrolepis, and gray cutthroat eel, Synaphobranchus affinis.

two species were totally absent in our stomach samples from this region. The total absence of walleye pollock and Pacific cod in the Baird's beaked whale stomach samples in spite of their abundance in the area is significant. It appears that while the whales are known to feed on T. chalcogramma in the Sea of Okhotsk, off the Pacific coast of Honshu they appear to prefer to feed in the benthopelagic environment on morid and macrourid fishes, probably at depths ranging from 800 to $1,200 \mathrm{~m}$.

The feeding preference of $B$. bairdii on benthic and epibenthic prey is similar to that of another deep-diving cetacean, the sperm whale, Physeter macrocephalus. Many of the fish species identified in our study have been reported from the stomachs of sperm whales taken off the Kurile Islands and the Pacific coast of northern Japan (Betesheva and Akimushkin 1955, Betesheva 1961, Berzin 1971). Almost all the cephalopod species from B. bairdii are known prey of sperm whales taken in the coastal waters of Japan (Okutani et al. 1976, Okutani and Satake 1978). An additional similarity between these two cetacean species is the common occurtence of stones and gravel in sperm whale stomachs (Berzin 1971). In the Pacific coast of Honshu B. bairdii sample, stones and gravel were noted in $100 \%$ of 98 stomachs surveyed for these non-food items. These were presumably ingested incidentally during benthic foraging. The southern Sea of Okhotsk sample demonstrated a different pattern. In this sample stones and gravel were found in only two (10\%) of the 20 whales examined. This low frequency of occurrence is probably due to their cephalopod feeding preference. Most of the cephalopod species consumed by $B$. bairdii in this region are 
muscular swift-swimming species that are not predominantly associated with the benthic environment.

In general, it has been assumed that beaked whales feed predominantly on cephalopods (Clarke 1996). However, since few ziphiids have been taken in whale fisheries, most dietary information on beaked whales has been derived from a small number of whales which had stranded or were incidentally taken by fisheries (Mead 1989). Berardius bairdii and the northern bottlenose whale, Hyperoodon ampullatus, are the only ziphiid species that have been direct targets of whale fisheries. As a result, $H$. ampullatus is the species for which we have the best beaked whale dietary information to use for comparison. Like B. bairdii, $H$. ampullatus also demonstrates deep-diving behavior with dives up to $1,453 \mathrm{~m}$ for durations of up to $70 \mathrm{~min}$ (Hooker and Baird 1999). Benjaminsen and Christensen (1979) reported on the stomach contents of 47 whales examined off Iceland in 1967 and 108 from Labrador in 1971. Unfortunately, like the dietary study of $B$. bairdii off Japan conducted by Nishiwaki and Oguro (1971), the authors also limited their dietary study on $H$. ampullatus to general qualitative observations on the presence or absence of fish and squid, though they did make some attempt to identify some of the common prey species. Geographical differences in the diet of the northern bottlenose whale were evident. They reported less than $10 \%$ of the whales from Iceland had eaten fish, while about $50 \%$ of the whales taken off Labrador had fish in their stomachs.

In their sample all the squid examined were identified as a single species, Gonatus fabricii. However, their cursory examination of the cephalopod prey remains may have led to an overly simplistic presentation of the cephalopods represented. Clarke and Kristensen (1980) conducted a detailed analysis of cephalopod beaks from two stranded $H$. ampullatus: one in Jutland and one in the Faroe Islands. They reported that while Gonatus fabricii was the dominant prey by number $(74 \%)$, the remaining $26 \%$ were represented by a wide variety of deep-water species representing seven other families.

Benjaminsen and Christensen (1979) reported, but did not quantify, the following fishes in their Iceland sample: Brosmizs brosme (Gadidae), Cyclopterus lumpus (Cyclopteridae), and Sebastes sp.(Scorpaenidae). The Labrador sample included Reinbardtius bippoglossoides (Pleuronectidae), Sebastes sp. (Scorpaenidae), Molva molva (Gadidae), Chimaera monostrosa (Chimaeridae), Squalus acantbius (Squalidae), and Raja sp. (Rajadae). All of the above species are common inhabitants of the deepwater benthic and epibenthic zones. However, considering the large sample size of 155 stomachs, the total absence of grenadiers (Macrouridae) in their list of fishes eaten by $H$. ampullatus is surprising. Two species of grenadiers, Coryphaenoides rupestris and Macrourus berglax are very abundant off the Labrador coast and Iceland at depths of 500-1,000 $\mathrm{m}$ where they have supported extensive international trawl fisheries since the mid-sixties (Cohen et al. 1990). It is possible that the cursory examination of the fish remains in the $H$. ampullatus stomachs resulted in their being selectively overlooked. Digestion in ziphiids occurs at a faster rate than most other cetaceans. Macrourids are comparatively soft-bodied fishes, and the stomach anatomy of ziphiids differs from most cetacean species in that the esophagus empties directly into the glandular, main (fundic) stomach (Mead 1989). As a result, the rapid digestion of soft-bodied fishes could have resulted in the reported absence of macrourids. In our sample from Japan, the rapid digestive process of $B$. bairdii rendered all the macrourids unrecognizable, other than through detailed examination of otoliths and skeletal remains. 
Though the methodology employed in the studies of B. bairdii and its North Atlantic congener, $H$. ampullatus, are not comparable in detail and may have excluded some species vulnerable to rapid digestion, it appears that the diet of these two species of large, deep-diving, ziphiids are generally similar. Geographic differences in the proportion of cephalopods and fish consumed are found in both species, and the prey species identified from the stomachs indicate both are feeding on benthic prey in at least some portions of their range.

\section{ACKNOWLEDGMENTS}

The generous cooperation of Mr. H. Shogi of the Gaibo Whaling Co., Ltd. made the sampling at his facility at Wadaura, Chiba Prefecture, possible. S. Myoshi and Y. Shimomichi provided cooperation and facilities for the sampling at Abashiri, Hokkaido. Mr. Toba, owner of the catcher vessel Koei Maru, provided cooperation and facilities for sample collection at Ayukawa. Toshio Kasuya and Hidehiro Kato helped coordinate the sampling during the 1985-1989 fishing seasons. J. Taguchi conducted the 1988 stomach sampling at Abashiri, Hokkaido. Jeff Drazen and Jerry Hoff provided otolith specimens and data which enabled us to develop regressions on prey size for several of the fish species. Hiroshi Ohizumi assisted us in obtaining the otolith length/standard length regression for the longfin codling from Mr. Nobetsu of Hokkaido University. We also thank Tomio Iwamoto, California Academy of Sciences and Osamu Okamura, Kochi University, Japan for providing invaluable advice and macrourid otolith reference specimens to complement the otolith identifications. Finally, we thank the three anonymous reviewers for constructive comments on the manuscript.

\section{Literature Cited}

BaLCOMB, K. C. 1989. Baird's beaked whale Berardius bairdii Stejneger, 1883: Arnoux's beaked whale Berardius arnuxii Duvernoy, 1851. Pages 261-288 in S. H. Ridgway and R. J. Harrison, eds. Handbook of marine mammals. Volume 4. Academic Press, London.

Benjaminsen, T., AND I. Christensen. 1979. The natural history of the bottlenose whale. Pages 143-164 in H. E. Winn and B. L. Olla, eds. Behavior of marine animals. Volume 3. Cetaceans. Plenum Press, New York, NY.

Berzin, A. A. 1971. The sperm whale. A. V. Yablokov, ed. Pishchevaya Promyshlennost, Moscow; translation by Israel Program for Scientific Translations, 1972.

Betesheva, E. I., And I. I. Akimushkin. 1955. Food of the sperm whale (Pbyseter catadon) in the Kurile Islands region. Trudy Instituta Okeanologii Akademii Nauk SSSR 18:86-94. (in Russian).

Betesheva, E. I. 1961. Pitanie promyslovykh kitov prikuril'skogo raiona. Pages 7-32 in A. G. Tomilin and B. S. Matveyev, eds. Kitoobrazniye dal'nevostochnykh morei. Trudy Instituta Morfologii Zhivotnykh, Moscow 34:1-231.

Clarke, M. R. 1996. Cephalopods as prey. III. Cetaceans. Philosophical Transactions of the Royal Society of London B 351:1053-1065.

Clarke, M. R., and T. Kristensen. 1980. Cephalopod beaks from the stomachs of two northern bottlenosed whales (Hyperoodon ampullatus). Journal of the Marine Biological Association, U. K. 60:151-156.

Cohen, D. M., T. Inada, T. IWamoto and N. SCialabba. 1990. FaO species catalogue. Volume 10. Gadiform fishes of the world (order Gadiformes). An annotated and illustrated catalogue of cods, hakes, grenadiers and other gadiform fishes known to date. FAO Fisheries Synopsis 125. 
Hamatsu, T., AND K. Yabuki. 1997. Maturity of Laemonema longipes in the Pacific area off eastern Hokkaido. Bulletin of the Hokkaido National Fisheries Research Institute 61:1-7.

Heyning, J. E., AND J. G. Mead. 1996. Suction feeding in beaked whales: morphological and observational evidence. Los Angeles County Museum Contributions in Science 464:1-12.

HOOKER, S. K., AND R. W. BAIRD. 1999. Deep-diving behavior of the northern bottlenose whale, Hyperoodon ampullatus (Cetacea: Ziphiidae). Proceedings of the Royal Society of London 266:671-676.

KasuYa, T. 1986. Distribution and behavior of Baird's beaked whales off the Pacific coast of Japan. Scientific Reports of the Whales Research Institute, Tokyo 37:61-83.

Kasuya, T., R. L. Browneli JR. AND K. C. Balcomb III. 1997. Life history of Baird's beaked whales off the Pacific coast of Japan. Report of the International Whaling Commission 47:969-979.

Masuda, H., K. Amaoka, C. Araga, T. Ueno and T. Yoshino, eds. 1984. Fishes of the Japanese Archipeligo. Tokai University Press, Tokyo.

Mead, J. G. 1989. Beaked whales of the genus Mesoplodon. Pages 349-430 in S. H. Ridgway and R. J. Harrison, eds. Handbook of marine mammals. Volume 4. Academic Press, London.

Nesis, K. N. 1987. Cephalopods of the world. TFH Publications Inc., Neptune City, NJ.

NeLson, J. S. 1994. Fishes of the world, 3rd edition. John Wiley and Sons Inc., New York, NY.

Nishiwaki, M., AND N. Oguro. 1971. Baird's beaked whales caught on the coast of Japan in recent 10 years. Scientific Reports of the Whales Research Institute, Tokyo 23:111-122.

Okamura, O. 1970a. Studies on the macrourid fishes of Japan-Morphology, ecology and phylogeny. Reports of the USA Marine Biological Station 17(1-2). 179 pp.

Okamura, O. 19706. Fauna Japonica, Macrourina (Pisces). Academic Press of Japan, Tokyo.

Okutani, T., And Y. Satake. 1978. Squids in the diet of 38 sperm whales caught in Pacific waters off northeastern Honshu, Japan, February, 1977. Bulletin of the Tokai Regional Fisheries Research Laboratory 93:13-27.

Okutani, T., Y. Satake, S. Ohsumi and T. Kawakasu. 1976. Squids eaten by sperm whales caught off Joban district, Japan, during January-February, 1976. Bulletin of the Tokai Regional Fisheries Research Laboratory 87:67-113.

Ohsumi, S. 1975. Review of Japanese small-type whaling. Journal of the Fisheries Research Board of Canada 32:1111-1121.

PIKE, G. C. 1953 . Two records of Berardius bairdii from the coast of British Columbia. Journal of Mammalogy 34:102-107.

RICE, D. W. 1963. Progress report on biological studies of the larger Cetacea in the waters off California. Norsk Hvalfangst-Tidende 52:181-187.

ShIRATORI M., AND K. KaWASAKI. 1989. Community structure of bottom fish on the continental slope off southern Sanriku. Report of the 1988 Fishery Resources Research Conference, Northern Japan Bottom Fish Group 22:73-82. (in Japanese)

Tomitrin, A. G. 1957. Zveri SSSR I Prilezhasfchikh Stran. Zveri Vostochnoi Evropy I Severnoi Azii. Volume IX. Kitoobraznye. Izdatel'stvo Akademi Nauk SSSR, Moscow. [Translated in 1967 as Mammals of the USSR and Adjacent Countries. Mammals of Eastern Europe and Adjacent Countries. Volume IX. Cetacea by the Israel Program for Scientific Translations, Jerusalem.]

Yokota M., AND T. KaWASAKI. 1990. Population biology of the forked hake, Laemonema longipes (Schmidt), off the eastern coast of Honshu, Japan. Tohoku Journal of Agricultural Research 40(3-4): 65-80. 